\title{
Pengaruh Keadilan terhadap Kepuasan dan Kepatuhan Wajib Pajak
}

\begin{abstract}
Albari
Universitas Islam Indonesia

albari@fe.uii.ac.id

In general, tax payment has been perceived merely as a citizen's obligation which has to be performed, paying less attention to the interests of Tax Payers. Therefore, this study proposes to reveal possibilities of Tax Payers' compliance because of just services given by Tax Office and of Tax Payers' satisfaction upon the justice itself. In this research, concept of justice is classified into distributive, procedural and interactional justices. This research involves 166 respondents, gained through convenience sampling from Tax Payers in KPP II. Using path analysis, this research results in the fact that justice affects, directly or indirectly, the compliance through intervening variable of satisfaction. Whilst based on regression analysis, it has been shown that distributive justice and the satisfaction of Tax Payers upon procedural justice positively affect the Tax Payers' compliance.
\end{abstract}

Keywords: justice, satisfaction, compliance.

\section{Pendahuluan}

Seiring dengan bergeraknya reformasi di Ssegala bidang, maka kebijakan keuangan pemerintah juga mengalami perubahan. Salah satu sumber pembiayaan aktivitas pemerintahan yang selama ini berasal dari utang luar negeri, semakin lama semakin dikurangi peranannya. Bahkan pada awal tahun 2007 ini Presiden SBY telah memutuskan untuk membubarkan consulting goverments for Indonesian (CGI) sebagai forum yang selama ini menjadi tumpuan untuk menutup defisit Anggaran Pendapatan dan Belanja Negara (APBN). Konsekuensi dari kebijakan tersebut pemerintah harus menggiatkan pendapatan yang bersumber dari dalam negeri. Salah satu yang diandalkan adalah dari sektor perpajakan.

Untuk itu, antisipasi internal-struktural oleh Direktorat Jendral Pajak (DJP) maupun wacana dari berbagai pihak telah dilakukan untuk meningkatkan ekstensifikasi pajak. Misalnya dengan rencana pembentukan direktorat penyidikan khusus dan menambah jumlah penyidik khusus; melakukan perubahan istilah wajib pajak (WP) menjadi pembayar pajak, sehingga orang tidak melihat pajak sebagai monster dan mempermudah dalam promosi; transparansi data tentang pegawai yang melakukan kesalahan, termasuk pemberian sanksi disiplin kepada 210 orang pada tahun 2006 yang lalu; serta wacana pembentukan Badan Penerimaan Perpajakan (BNP) yang langsung di bawah Presiden menggantikan DJP yang masih di bawah Departemen Keuangan (Depkeu), karena dinilai jangkauan kewenangan Depkeu sudah overload (Jawa Pos, 2006, 2007a dan 2007b). Bahkan, pada saat ini DJP juga telah memberi peluang pembayaran pajak secara elektronik. Namun sistem ini belum dimanfaatkan secara signifikan, karena WP masih banyak memanfaatkan cara pembayaran kenvensional dengan langsung datang ke Kantor Pajak.

Usaha-usaha untuk meningkatkan ekstensifikasi pajak tersebut kemungkinan 
akan lebih berhasil, jika DJP juga mampu meningkatkan pemenuhan kepentingan WP. Dalam perspektif WP, WP memang harus memenuhi kewajiban membayar pajak tanpa mendapat imbalan langsung atau serta merta, bahkan setiap kelalaian akan mendapatkan sanksi/hukuman pidana. Oleh karena itu terpenuhinya kepentingan dan kepuasan WP menjadi sangat penting, sebab hanya kondisi tersebut satu-satunya yang dapat diperoleh mereka. Hal ini berbeda dengan konsumen produk/jasa yang dapat bebas (suka rela) melakukan transaksi dengan penyedia produk/jasa serta bisa memperoleh langsung atribut dan manfaat setelah mengkonsumsi atau menggunakan produk/jasa tersebut.

Dalam proses pembayaran pajak, kepentingan WP dapat dipenuhi dengan pemberian perlakuan yang berkeadilan dari DJP atau Kantor Pajak. Keadilan tersebut dapat dikelompokkan menjadi keadilan distributif, prosedural dan interaksional (Huang and Lin, 2005). Secara teoritik, pemenuhan keadilan yang diberikan secara optimal oleh DJP atau kantor pajak kepada WP, akan berpengaruh terhadap tingkat kepuasan WP dalam proses pembayaran pajak. Pada akhirnya tingkat kepuasan akan menimbulkan kepatuhan mereka, terutama berkaitan dengan pembayaran pajak pada periode berikutnya.

\section{Kajian Pustaka}

Teori keadilan sebelumnya diterapkan dalam pemasaran, karena adanya kelalaian pemberian jasa dan keluhan pelanggan (Tax, Brown and Chandrashekaran, (1998). Menurut Huang and Lin (2005), rasa keadilan merupakan evaluasi pendapat tentang kelayakan perlakuan seseorang terhadap orang lain. Selanjutnya Huang and Lin (2005) membagi keadilan menjadi dimensi keadilan distributif, prosedural dan interaksional, sementara Zeithamal, Bitner and Gremler (2006) menyebutnya sebagai kelayakan hasil [distribusi], prosedural dan interaksional. Mereka menyatakan bahwa Keadilan distributif merupakan tingkat kelayakan hasil akhir kegiatan yang dirasakan pelanggan dari keluhan mereka, meskipun bukan berarti harus menguntungkan atau tidak menguntungkan pelanggan. Keadilan ini berkaitan dengan alokasi sumber daya atau kompensasi, seperti pengembalian dana atau potongan pembayaran.

Adapun keadilan prosedural berupa persepsi kelayakan dari kebijakan, prosedur, peraturan dan ketepatan waktu yang berkaitan dengan usaha-usaha dan proses perbaikan keluhan. Sedangkan keadilan interaksional adalah kelayakan untuk menerima perlakuan interpersonal selama pelaksanaan suatu prosedur atau proses keluhan, dan selama interaksi terjadi individu mengharapkan rasa hormat yang tinggi.

Lebih jauh Huang and Lin (2005) menyatakan penerapan keadilan akan lebih optimal, jika pengambil keputusan memberikan penjelasan berbentuk alasan dan pembenaran. Pada penjelasan berbentuk alasan, pengambil keputusan mengakui bahwa kegiatan yang dilakukan tidak menguntungkan serta meniadakan tanggung jawab organisasi dengan menyebutkan alasan yang disebabkan oleh beberapa faktor eksternal. Sementara pada penjelasan berbentuk pembenaran, pengambil keputusan menerima seluruh tanggung jawab, tetapi mengingkari bahwa kegiatan yang dilakukan tidak tepat, dengan maksud untuk memenuhi beberapa tujuan utama mereka sendiri. Penjelasan berbentuk pembenaran kemungkinan akan memberi pengaruh yang lebih tinggi kepada persepsi keadilan dibandingkan dengan penjelasan berbentuk alasan. Akhirnya, mereka menyimpulkan bahwa keadilan berpengaruh secara langsung maupun tidak langsung terhadap loyalitas melalui kepuasan pelanggan. 
UNISIA, Vol. XXXI No. 69 September 2008

Di samping itu hasil penelitian Folger and Konovsky (1989) menunjukkan bahwa keadilan distributif bisa menjelaskan perbedaan kepuasan yang lebih unik dari pada keadilan prosedural, tetapi keadilan prosedural dapat menjelaskan perbedaan yang lebih unik tentang sikap terhadap institusi dan orang yang berkuasa, kepercayaan kepada pengawas dan komitmen organisasi.

Dalam konteks [proses] pembayaran pajak, istilah pelanggan lebih umum disebut sebagai wajib pajak (WP), sedangkan pengertian loyalitas pelanggan lebih umum disebut sebagai kepatuhan WP (Cords, 2006; Goldman, 2006; Fitriandi, Birowo, dan Aryanto, 2007), sehingga hipotesis yang diajukan berkenaan dengan tiga variabel tersebut adalah:

Dalam hubungan keadilan dengan kepuasan:

$\mathrm{H} 1$ : Ada pengaruh positif keadilan kantor pajak terhadap tingkat kepuasan WP

H1a: Ada pengaruh positif keadilan distributif kantor pajak terhadap tingkat kepuasan WP

$\mathrm{H} 1 \mathrm{~b}$ : Ada pengaruh positif keadilan prosedural kantor pajak terhadap tingkat kepuasan WP

H1c: Ada pengaruh positif keadilan interaksional kantor pajak terhadap tingkat kepuasan WP

kepatuhan:

Dalam hubungan keadilan dengan

H2 : Ada pengaruh positif keadilan kantor pajak terhadap tingkat kepatuhan WP

H2a : Ada pengaruh positif keadilan distributif kantor pajak terhadap tingkat kepatuhan WP

$\mathrm{H} 2 \mathrm{~b}$ : Ada pengaruh positif keadilan prosedural kantor pajak terhadap tingkat kepatuhan WP
H2c: Ada pengaruh positif keadilan interaksional kantor pajak terhadap tingkat kepatuhan WP

Dalam teori pemasaran senantiasa ditekankan pentingnya manajemen/ organisasi untuk memperhatikan tingkat kepuasan pelanggannya. Disney (1999) menunjukkan pengalaman empiris tentang pentingnya pemahaman tentang kepuasan pelanggan tersebut dengan mengungkapkan suatu penelitian di Amerika bahwa hanya $4 \%$ pelanggan yang tidak puas melakukan protes, dan yang $96 \%$ yang tidak puas ratarata menceriterakan kepada sembilan atau sepuluh orang lain tentang ketidakpuasan. Hal itu memberikan pelajaran besarnya potensi kerugian organisasi, jika mengabaikan tingkat kepuasan pelanggannya.

Lebih jauh Stephens and Gwinner (1998) menyatakan pelanggan yang tidak mengeluh karena ketidakpuasannya perlu mendapat perhatian khusus manajemen, karena beberapa alasan, yaitu (1) berkurangnya kesempatan untuk memperbaiki masalah dan mempertahankan pelanggan, (2) reputasi perusahaan dapat rusak karena adanya komunikasi lesan yang negatif, yang dilakukan pelanggan yang tidak puas, sehingga memungkinkan berkurangnya pelanggan sekarang dan potensial, dan (3) menghilangkan arus-balik yang berharga tentang kualitas produk/jasa, sehingga mengganggu kemampuan untuk mengenali perbedaan kualitas dan membuat perbaikan. Karena itu, manager sangat perlu untuk memahami tidak hanya orang yang memberikan keluhan, tetapi juga kepada mereka yang tidak bersedia untuk protes.

Chang and Tu (2005) menyatakan bahwa kepuasan pelanggan sebagai evaluasi pelanggan setelah berperilaku pada tempat dan waktu tertentu. Tian-Cole, 
Pengaruh Keadilan terhadap Kepuasan dan...; Albari

Crompton and Wilson (2002) menilai kepuasan dari hasil psikologis pelanggan pada pengalaman langsung yang lalu. Kepuasan seperti tersebut dapat diukur secara langsung (Yu, Chang and Huang, 2006), melalui pernyataan perasaan menyenangkan - tidak menyenangkan, puas-tidak puas atau positif-negatif (TianCole, Crompton and Wilson, 2002).

Kepuasan juga dapat diukur dengan dimensi kognitif, afektif, dan konatif (Leo dan Philippe, 2002). Kepuasan berdimensi kognitif diperoleh dari hasil langsung pengalaman sesudah berperilaku, dimensi afektif dari emosi dan rasa senang yang timbul dari pengalaman, dan konatif diimplikasikan dengan kegiatan untuk berperilaku ulang dan merekomendasikan pada orang lain

Lebih lanjut, Barsky and Labagh (1992) menyatakan bahwa tujuan utama penilaian kepuasan adalah untuk menentukan sebanyak mungkin kepentingan pelanggan. Karena itu indikator pengukuran kepuasan bisa terdiri dari banyak faktor, seperti yang dilakukan Lawton, Weaver and Faulkner (1998), Yuksel and Rimington (1998), Voss, Parasuraman and Grewal (1998), Meuter at al. (2000), serta Jun at al. (2001).

Berkaitan dengan keterkaitan antara kepuasan dengan loyalitas pelanggan, Bloemer, Ruyter and Peeters (1998), Grisaffe (2001) serta Yu, Chang and Huang (2006) membuktikan bahwa kepuasan berpengaruh terhadap loyalitas. Karena itu, berkaitan dengan [proses] pembayaran pajak, maka diajukan hipotesis sebagai berikut:

H3 : Ada pengaruh positif tingkat kepuasan WP [pada keadilan kantor pajak] terhadap tingkat kepatuhan mereka

H3a: Ada pengaruh positif tingkat kepuasan WP [pada keadilan distributif kantor pajak] terhadap tingkat kepatuhan mereka

H3b : Ada pengaruh positif tingkat kepuasan WP [pada keadilan prosedural kantor pajak] terhadap tingkat kepatuhan mereka

H3c: Ada pengaruh positif tingkat kepuasan WP [pada keadilan interaksional kantor pajak] terhadap tingkat kepatuhan mereka

Kepatuhan adalah sebuah sikap yang rela untuk melakukan segala sesuatu, yang di dalamnya didasari kesadaran maupun adanya paksaan, yang membuat perilaku seseorang dapat sesuai dengan yang diharapkan (Mc Mahon, 2001). Mc Mahon (2001) juga mengartikan kepatuhan sebagai kegiatan individu untuk menjalankan kewajibannya dalam memberikan kontribusi pada pemenuhan kewajiban sesuai dengan peraturan yang mengaturnya. Berkaitan dengan kewajiban pembayaran pajak, maka kepatuhan dalam membayar pajak juga merupakan sikap patriotis warga Negara. Pada prinsipnya orang yang patuh yaitu orang yang memiliki keputusan untuk memilih taat membayar pajak dan terhadap hukum (Goldman, 2006).

Kebijakan atau kegiatan yang bisa menimbulkan persepsi, bahwa pajak itu adil bagi semua orang akan sangat membantu menyadarkan WP memenuhi kewajibannya untuk membayar pajak (Mc Mahon, 2001). Oleh karena itu, perlakuan yang dapat mengarahkan kepada kepatuhan membayar pajak sangat penting untuk dilakukan dengan tujuan untuk meningkatkan jumlah orang yang patuh (Cords, 2006). Hal ini dapat dicapai, misalnya dengan melakukan pemeriksaan dalam penetapan pajak WP oleh petugas pemeriksa pajak untuk menguji pemenuhan kewajiban perpajakan para WP (Fitriandi, Birowo dan Aryanto, 
UNISIA, Vol. XXXI No. 69 September 2008

2007). Pemeriksaan pajak tersebut akan mendorong WP untuk memahami peraturan pajak yang berlaku, sehingga bisa mengisi dokumen pajaknya dan melakukan proses pembayaran dengan benar serta bersedia membayar pajak secara periodik.

Berdasarkan penjelasan tentang keadilan, kepuasan dan kepatuhan tersebut di atas, maka dapat dibuat hubungan antara variabel seperti yang terlihat pada Gambar 1 .
Pengumpulan data dilakukan dengan menggunakan angket tertutup, berupa butirbutir pernyataan yang sesuai dengan variabel-variabel penelitian tentang keadilan dan kepuasan (distributif, prosedural, interaksional) serta kepatuhan. Tanggapan untuk setiap butir pernyataan disediakan dengan skala 4 ruas mulai dari (1) sangat tidak setuju sampai dengan (4) sangat setuju.

Adapun isi pernyataan setiap variabel penelitian seperti ditunjukkan dalam Tabel 1.

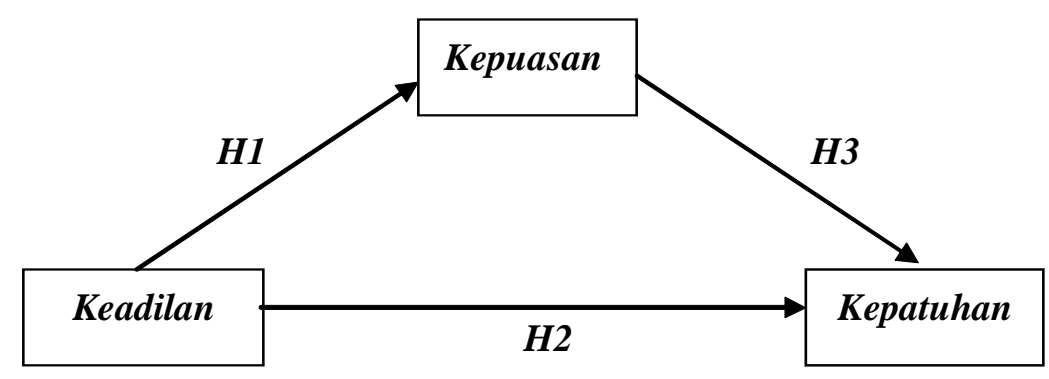

Gambar 1: Model Penelitian

\section{Metode Penelitian}

\section{Subjek Penelitian dan Pengumpulan Data}

Data penelitian ini diperoleh dari wajib pajak (WP) perseorangan yang sedang melakukan proses pembayaran pajak di Kantor Pelayanan Pajak (KPP) Wilayah II Yogyakarta Sampel diambil sebanyak 166 orang berdasarkan pada tarafkeyakinan sebesar $1 \%$ dan batas toleransi kesalahan data sebanyak 10\%. Sedangkan teknik pengambilan sampel menggunakan convenience sampling.

\section{Metode Analisis Data}

Data yang diperoleh dianalisis dengan menggunakan pendekatan rata-rata hitung, analisis jalur dan analisis regresi. Rata-rata hitung digunakan untuk menentukan kecenderungan dominasi atau nilai relatif suatu butir pernyataan dibandingkan dengan butir pernyataan yang lain, serta kelebihan antara nilai suatu butir pernyataan dari variabel keadilan, kepuasan dan kepatuhan.

Adapun penggunaan analisis jalur dimaksudkan untuk menguji adanya 
Pengaruh Keadilan terhadap Kepuasan dan...; Albari

Tabel 1: Isi Pernyataan Angket setiap Variabel Penelitian

\begin{tabular}{|l|}
\hline \multicolumn{1}{|c|}{ Keadilan dan Kepuas an [pada keadilan] Distributif } \\
\hline Kantor pajak menetapkan jumlah pajak yang seharusnya dibayar oleh setiap WP \\
\hline $\begin{array}{l}\text { Kantor pajak akan memberikan pengembalian kelebihan pembayaran pajak kepada setiap } \\
\text { WP }\end{array}$ \\
\hline Kantor pajak menetapkan jumlah denda pajak yang seharusnya dibayar oleh setiap WP \\
\hline \multicolumn{1}{|c|}{ Keadilan dan Kepuasan [pada keadilan] Prosedural } \\
\hline Kantor pajak memberlakukan prosedur pembayaran pajak yang sama kepada setiap WP \\
\hline $\begin{array}{l}\text { Kantor pajak memberlakukan peraturan pengembalian kelebihan pembayaran yang sama } \\
\text { kepada setiap WP }\end{array}$ \\
\hline Kantor pajak memberlakukan kebijakan pembayaran denda yang sama kepada setiap WP \\
\hline Pegawai kantor pajak memberikan kecepatan pelayanan waktu yang sama kepada setiap WP \\
\hline \multicolumn{2}{|c|}{ Keadilan dan Kepuasan [pada keadilan] Interaksional } \\
\hline Setiap WP mendapat rasa hormat yang sama selama proses pembayaran pajak \\
\hline Setiap WP mendapat rasa nyaman yang sama selama proses pembayaran pajak \\
\hline Setiap WP mendapat keramahan yang sama selama proses pembayaran pajak \\
\hline \multicolumn{1}{c|}{ Kepatuhan } \\
\hline Bersedia terus membayar pajak pada periode yang akan datang \\
\hline $\begin{array}{l}\text { Tidak bersedia menerima tawaran dalam proses pembayaran pajak yang tidak sesuai } \\
\text { prosedur dari pihak lain }\end{array}$ \\
\hline Bersedia untuk memahami peraturan perpajakan di masa mendatang \\
\hline
\end{tabular}

pengaruh langsung maupun tidak langsung variabel keadilan terhadap kepatuhan melalui variabel antara kepuasan. Sedangkan analisis regresi digunakan untuk menguji adanya pengaruh dimensi variabel keadilan (distributif, prosedural dan interaksional) terhadap kepuasan atau kepatuhan serta pengaruh dimensi variabel kepuasan (pada keadilan distributif, prosedural dan interaksional) terhadap kepatuhan. Penggunaan analisis regresi akan dilakukan, jika hasil analisis jalur berhasil menunjukkan pengaruh langsung atau tidak langsung variabel independen terhadap dependen. Di samping itu, kedua kelompok pengujian analisis pengaruh tersebut menggunakan batas kritis (signifikansi/á) sebesar 5\%.

\section{Hasil Analisis dan Pembahasan Analisis Deskriptif}

Dari 166 angket yang disebarkan seluruhnya diisi responden sesuai dengan yang diminta oleh peneliti, sehingga dapat digunakan untuk data analisis. Selanjutnya data tersebut dilakukan pengujian validitas dan reliabilitas data dengan pendekatan Pearson Correlation pada taraf signifikansi $5 \%$ serta Alpha Cronbach dengan nilai kritis 0,6 . Dengan menggunakan program pengolah data SPSS versi 13.0, pengujian menunjukkan hasil bahwa semua butir pernyataan dalam kondisi yang valid dan reliable.

Adapun hasil diskripsi data yang ditentukan dengan rata-rata ditunjukkan dalam Tabel 2.

Mendasarkan pada skala data 1-4, maka Tabel 2 menunjukkan bahwa butir-butir pernyataan dari variabel keadilan, kepuasan [pada keadilan] dan kepatuhan sudah cenderung dinilai di atas rata-rata, karena melebihi nilai tengah skala data sebesar 2,50 , baik secara rata-rata total maupun 
UNISIA, Vol. XXXI No. 69 September 2008

berdasarkan rata-rata masing-masing atribut. Hal itu berarti responden cenderung menyatakan setuju bahwa KPP II telah memberikan keadilan pelayanan proses pembayaran pajak kepada setiap WP, dan bahwa responden juga telah merasa puas dengan keadilan pelayanan tersebut, serta akan mematuhi untuk melaksanakan peraturan perpajakan pada waktu yang akan datang.
Jika dilakukan pembandingan penilaian antara rata-rata keadilan pelayanan proses pembayaran pajak dengan rata-rata kepuasan pada keadilan pelayanan pajak, Tabel 2 juga memberikan informasi bahwa kepuasan WP pada keadilan yang diterimanya seluruhnya menunjukkan nilai yang lebih rendah dibandingkan dengan penilaian keadilan yang diberikan oleh pegawai dan kantor pajak kepada WP, kecuali pada atribut keadilan

Tabel 2: Rata-rata Tanggapan Responden pada Variabel Keadilan, Kepuasan dan Kepatuhan

No.

1

Kantor

seharus

Kantor 1

pembay

Kantor 1

seharust

2 Kantor 1

yang sat

Kantor

kelebiha

Kantor 1

yang sal

Pegawa

waktu y

3 Setiap V pembay

Setiap V pembay

Setiap V

pembay:

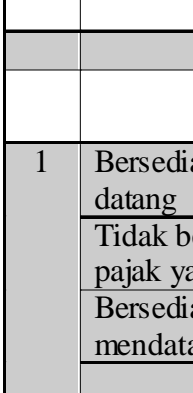


Pengaruh Keadilan terhadap Kepuasan dan...; Albari

distributif tentang penetapan jumlah denda pajak yang seharusnya dibayar oleh setiap WP. Atribut tersebut serta atribut keadilan prosedural tentang pemberlakuan kebijakan pembayaran denda yang sama kepada setiap WP juga menunjukkan kecenderungan yang berbeda; jika atribut yang lain menunjukkan arah perubahan dengan besarnya hasil penilaian yang relatif searah (rata-rata keadilan rendah dan rata-rata kepuasan rendah, atau sebaliknya), sedangkan kedua atribut tersebut menghasilkan nilai rata-rata keadilan rendah, namun dengan rata-rata kepuasan cukup tinggi. positif terhadap kepatuhan, masing-masing dengan nilai jalur 0,254 dan 0,224. Penjelasan tersebut sekaligus dapat untuk menetapkan bahwa hipotesis 1, 2 dan 3 seluruhnya terbukti secara signifikan.

Di samping itu dari Tabel 3 dapat diketahui pula bahwa jumlah variance kepuasan yang tidak dijelaskan (e) oleh variabel keadilan sebesar $(1-0,351)^{2}=0,421$. Sedangkan untuk variabel kepatuhan, maka jumlah variance yang tidak dijelaskan oleh keadilan dan kepuasan adalah $(1-0,182)^{2}=$ 0,669 .

\section{Tabel 3: Rekapitulasi Hasil Analisis Regresi}

\begin{tabular}{|c|c|c|c|c|c|}
\hline No. & Variabel & Koef. Beta & Prob (t) & Prob (F) & \\
\hline 1 & Keadilan $\rightarrow$ kepuasan & 0,593 & $0.000^{-}$ & & \\
\hline 2 & $\begin{array}{l}\text { Keadilan } \rightarrow \text { kepatuhan } \\
\text { Kepuasan } \rightarrow \text { kepatuhan }\end{array}$ & $\begin{array}{l}0,254 \\
0,224\end{array}$ & $\begin{array}{l}\text { GâA Ba } \\
0,01 \mathrm{Be}\end{array}$ & & 0,182 \\
\hline
\end{tabular}
kepuasan serta pengaruh variabel keadilan dan kepuasan terhadap kepatuhan. Ringkasan hasil analisis regresi tersebut ditunjukkan dalam Tabel 3.

Dari Tabel 3 dapat diketahui pada persamaan (1) koefisien [standarized] beta variabel keadilan adalah sebesar 0,593 dan signifikan pada 0,000 . Hal itu berarti bahwa secara positif keadilan mempengaruhi kepuasan dengan nilai path atau jalur sebesar 0,593. Sedangkan pada persamaan regresi (2) koefisien beta untuk variabel keadilan adalah 0,254 dan signifikan pada 0,004 serta variabel kepuasan sebesar 0,224 dan signifikan pada 0,012 . Hal itu berarti keadilan dan kepuasan berpengaruh tersebut dapat ditentukan bahwa keadilan yang diberikan oleh kantor pajak KPP II dapat berpengaruh langsung terhadap kepatuhan WP untuk membayar pajak. Variabel keadilan tersebut juga dapat berpengaruh secara tidak langsung terhadap kepatuhan WP melalui variabel antara kepuasan WP. Besarnya pengaruh total dari kedua variabel tersebut (keadilan dan kepuasan) terhadap kepatuhan adalah sebesar 0,387 , yaitu dari $0,254+(0,593 x$ $0,224)$.

\section{Analisis Regresi Linier Berganda.}

Hasil analisis jalur menunjukkan ada pengaruh langsung maupun tidak langsung 
UNISIA, Vol. XXXI No. 69 September 2008

variabel keadilan terhadap kepatuhan melalui kepuasan konsumen. Oleh karena itu diperlukan pendalaman analisis untuk mengungkap lebih rinci tentang kemungkinan adanya pengaruh masingmasing dimensi keadilan dan kepuasan terhadap kepatuhan melalui pendekatan analisis regresi. t). Hal ini berarti hipotesis penelitian 1a, 1b, dan 1c harus dinyatakan ditolak. Hal itu berarti adanya pengaruh positif keadilan distributif, prosedural dan interaksional kantor pajak terhadap tingkat kepuasan WP tidak terbukti secara signifikan.

Pada kelompok analisis regresi yang kedua terdapat dua analisis regresi (2a dan

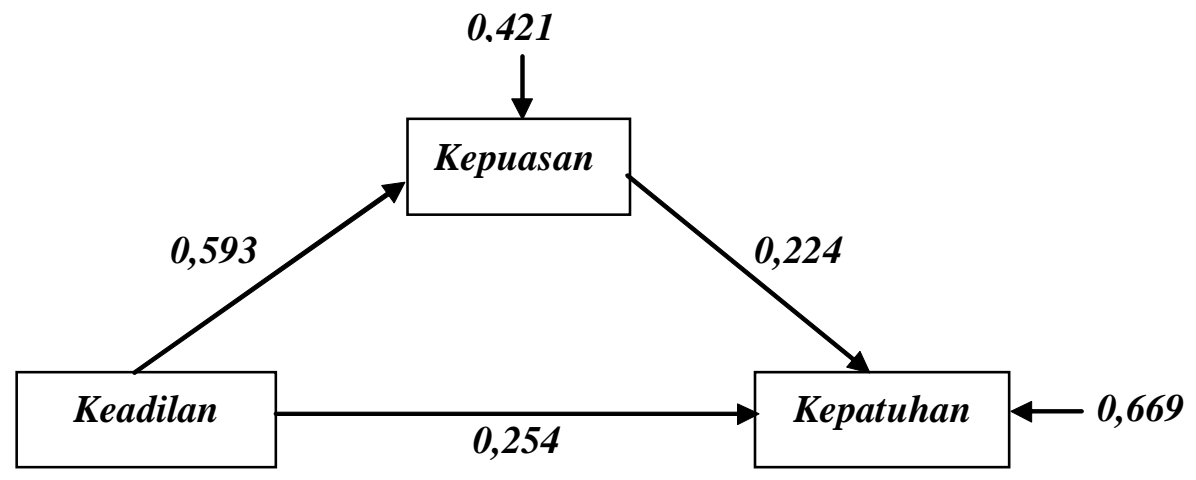

Gambar 2: Pengaruh Keadilan dan Kepuasan terhadap Kepatuhan

Dari data yang diperoleh dapat dilakukan 3 kelompok analisis regresi, yang hasil perhitungannya bisa diringkas seperti yang ditunjukkan dalam Tabel 4.

Tabel 4 menunjukkan 3 kelompok hasil analisis regresi, yaitu (1) pengaruh positif dimensi variabel keadilan terhadap kepuasan, (2) pengaruh positif dimensi variabel keadilan terhadap kepatuhan, serta (3) pengaruh positif dimensi variabel kepuasan (pada keadilan) terhadap kepatuhan.

Pada analisis regresi yang pertama, hasil persamaan regresi yang terbentuk ternyata menunjukkan dimensi variabel keadilan pelayanan proses pembayaran pajak kepada setiap WP tidak berpengaruh secara positif dan signifikan terhadap kepuasan WP, baik secara keseluruhan/ serentak (uji-F) maupun secara parsial (uji- 2b). Analisis regresi (2a) menunjukkan probabilitas signifikansi $\mathrm{F}$ (satu sisi/arah) sebesar 0,038 (3,8\%). Karena probabilitas tersebut lebih rendah dari taraf signifikansi kritis (á) 5\%, maka secara serempak hasil persamaan regresi yang terbentuk seharusnya dinyatakan teruji secara signifikan. Namun jika dilihat secara parsial ternyata hanya dimensi keadilan distributif saja yang mempunyai probabilitas signifikansi di bawah 5\%, sedangkan pada dimensi keadilan prosedural dan interaksional lebih dari $5 \%$. Hal itu berarti hanya hipotesis $2 a$ saja yang diterima, sehingga dapat dikatakan bahwa hanya dimensi keadilan distributif kantor pajak yang berpengaruh secara positif terhadap kepatuhan WP. Kesimpulan ini lebih diperkuat lagi dengan hasil analisis regresi lugas (2b), yang menunjukkan bahwa hasil probabilitas signifikansi uji-t [dan uji-F) 
Pengaruh Keadilan terhadap Kepuasan dan...; Albari

Tabel 4: Rekapitulasi Hasil Analisis Regresi (1) Keadilan-Kepuasan, (2) Keadilan-Kepatuhan serta (3) Kepuasan-Kepatuhan

\begin{tabular}{|c|c|c|c|c|c|c|}
\hline No. & Variabel & Koef. B & Prob (t) & Prob (F) & Adj $R^{2}$ & $\mathrm{r}^{2}$ \\
\hline 1 & $\begin{array}{l}\text { Konstanta } \\
\text { Distributif } \\
\text { Prosedural } \\
\text { Interaksional }\end{array}$ & $\begin{array}{c}2,621 \\
0,003 \\
0,135 \\
-0,072\end{array}$ & $\begin{array}{l}0,327 \\
0,057 \\
0,136\end{array}$ & 0,104 & 0,010 & $\begin{array}{c}1,225^{-03} \\
0,015 \\
7,396^{-03}\end{array}$ \\
\hline $2 \mathrm{a}$ & $\begin{array}{l}\text { Konstanta } \\
\text { Distributif } \\
\text { Prosedural } \\
\text { Interaksional }\end{array}$ & $\begin{array}{c}2,394 \\
0,134 \\
0,075 \\
-0,013\end{array}$ & $\begin{array}{l}0,045 \\
0,219 \\
0,430\end{array}$ & 0,038 & 0,024 & $\begin{array}{c}0,018 \\
3,721^{-03} \\
1,96^{-04}\end{array}$ \\
\hline $2 b$ & $\begin{array}{l}\text { Konstanta } \\
\text { Distributif }\end{array}$ & $\begin{array}{l}2,492 \\
0,162\end{array}$ & 0,006 & 0,006 & 0,032 & --- \\
\hline $3 a$ & $\begin{array}{l}\text { Konstanta } \\
\text { Distributif } \\
\text { Prosedural } \\
\text { Interaksional }\end{array}$ & $\begin{array}{c}1,776 \\
0,112 \\
0,352 \\
-0,050 \\
\end{array}$ & $\begin{array}{l}0,110 \\
0,000 \\
0,254 \\
\end{array}$ & 0,000 & 0,169 & $\begin{array}{c}9,216^{-03} \\
0,104 \\
2,704^{-03}\end{array}$ \\
\hline $3 b$ & $\begin{array}{l}\text { Konstanta } \\
\text { Prosedural }\end{array}$ & $\begin{array}{l}1,925 \\
0,363 \\
\end{array}$ & 0,000 & 0,000 & 0,170 & --- \\
\hline
\end{tabular}

koefisien regresinya di bawah $5 \%$, dengan variance kepatuhan yang dijelaskan oleh keadilan distributif sebesar 3,2\%.

Adapun kelompok ketiga dari analisis regresi terdiri dari analisis regresi (3a) dan (3b). Pada analisis regresi (3a), pengujian persamaan regresi secara serempak (uji-F) menunjukkan hasil yang sangat signifikan, karena probabilitas signifikansinya di bawah taraf kritis (á) $5 \%$ atau sebesar 0,000. Tetapi jika ditinjau secara parsial ternyata hanya dimensi kepuasan WP pada keadilan prosedural saja yang menghasilkan probabilitas yang signifikan $(0,000)$, sementara untuk kepuasan WP pada keadilan distributif dan interaksional lebih besar dari á, yaitu sebesar 0,110 dan 0,254. Lebih jauh hasil tersebut dikuatkan oleh analisis regresi sederhana (3b), yang menunjukkan ternyata memang dimensi kepuasan WP pada keadilan prosedural berpengaruh secara positif dan signifikan terhadap kepatuhan WP (probabilitas uji-t dan uji-F sebesar 0,000 ), dan dengan variance penjelas sebesar $17 \%$. Dengan demikian dapat disimpulkan bahwa hipotesis $3 \mathrm{~b}$ dapat terbukti secara signifikan, sedangkan hipotesis 3a dan 3c dinyatakan harus ditolak.

Hasil pengujian hipotesis dengan menggunakan analisis jalur (Tabel 3) menunjukkan bahwa penerapan keadilan yang diberikan oleh kantor pajak kepada WP secara langsung dan positif dapat berpengaruh terhadap kepatuhan WP di masa mendatang. Keadilan kantor pajak tersebut juga secara tidak langsung terbukti berpengaruh positif terhadap kepatuhan WP melalui kepuasan WP setelah menerima perlakuan keadilan kantor pajak. Namun 
UNISIA, Vol. XXXI No. 69 September 2008

kesimpulan hasil perhitungan yang didasarkan pada rata-rata total nilai masingmasing variabel, yang dipakai dalam model analisis jalur tersebut, tidak seluruhnya mendapat dukungan secara empiris, apabila analisis dilakukan berdasarkan dimensidimensi variabel keadilan dan kepuasan (Tabel 4).

Hal itu dapat diartikan bahwa untuk meningkatkan kepuasan WP pada keadilan kantor pajak, maka kantor pajak tidak perlu menerapkan pembedaan perlakuan berdasarkan pada dimensi-dimensi keadilan (distributif, prosedural atau interaksional), tetapi memberikan kebijakan dan pelayanan dalam proses pembayaran pajak secara bersamasama seperti yang telah diberikannya selama ini kepada WP (Tabel 2).

Di samping itu, untuk meningkatkan kepatuhan WP, kantor pajak perlu mengintensifkan semua aspek kebijakan dan pelayanan keadilan yang telah dilakukan, terutama yang berkaitan dengan dimensi keadilan distributif. Kantor pajak juga perlu senantiasa berusaha untuk meningkatkan kepuasan WP pada keadilan kantor pajak, khususnya tentang kepuasan yang berkaitan dengan keadilan prosedural kantor pajak. Jika dikaitkan dengan hasil Tabel 2, maka aspek keadilan distributif yang perlu ditingkatkan oleh kantor pajak adalah tingkat akurasi dalam menetapkan jumlah pajak yang seharusnya dibayar oleh setiap WP, sedangkan keadilan prosedural yang perlu ditonjolkan adalah konsistensi kantor pajak untuk memberlakukan prosedur pembayaran pajak yang sama kepada setiap WP.

Lebih lanjut Tabel 4 menginformasikan bahwa keadilan interaksional secara konsisten tidak berpengaruh secara positif dan signifikan terhadap kepuasan atau kepatuhan WP. Hal ini bisa memberikan dua pengertian yang kontradiktif, yaitu WP menganggap aspek-aspek keadilan interaksional tidak penting untuk diperhatikan atau diperolehnya, karena WP menganggap pembayaran pajak adalah suatu kewajiban warga negara yang harus ditunaikan. Sebaliknya, WP menganggap aspek-aspek keadilan interaksional penting untuk diberikan kepadanya, tetapi tidak perlu berkaitan dengan perasaan puas-tidak puas WP dan kepatuhan WP di masa mendatang, karena aspek-aspek tersebut sudah seharusnya dilakukan oleh kantor pajak sebagai imbalan atas pendapatan yang diperoleh kantor pajak dari pembayaran pajak WP. Jika melihat Tabel 2 yang menunjukkan bahwa keadilan interaksional mempunyai rata-rata yang lebih tinggi dibandingkan keadilan distributif dan prosedural, maka nampaknya pengertian kedua yang lebih tepat. Dengan kata lain, kantor pajak tetap perlu menerapkan aspekaspek keadilan interaksional tersebut bersamaan dengan keadilan distributif dan prosedural.

Dari pembandingan antara rata-rata keadilan dan rata-rata kepuasan (Tabel 2) dapat diketahui hampir seluruh nilai rata-rata atribut menunjukkan bahwa rata-rata kepuasan lebih rendah dari pada rata-rata keadilan. Hasil penilaian tersebut adalah sesuatu kondisi yang normal bahwa suatu peraturan, kegiatan, atau kebijakan mungkin sudah dianggap baik, namun belum tentu memuaskan semua pihak yang terlibat di dalamnya. Tetapi jika ditinjau dari sistematika model hubungan variabel bahwa seharusnya kepuasan lebih penting untuk menjadi perhatian manajemen dari pada keadilan, maka sudah seharusnya kantor pajak perlu memperbaiki kinerjanya agar kepuasan WP dapat ditingkatkan, utamanya pada atribut-atribut yang selisih rata-rata keadilan-kepuasannya relatif ekstrim, seperti pemberlakuan prosedur pembayaran dan peraturan pengembalian kelebihan 
Pengaruh Keadilan terhadap Kepuasan dan...; Albari

pembayaran (dimensi prosedural) serta pemberian rasa hormat, kenyaman dan keramahan yang sama kepada setiap WP (dimensi interaksional).

\section{Penutup}

Penelitian ini berhasil membuktikan adanya pengaruh positif dan langsung maupun tidak langsung dari keadilan terhadap kepatuhan melalui variabel antara kepuasan. Pada dataran aplikatif, hasil penelitian bisa berguna untuk memperbaiki kinerja sistem perpajakan yang ada, khususnya untuk KPP Yogyakarta II. Namun manfaat yang lebih banyak mungkin bisa berguna sebagai pengembangan teoritis, utamanya model penelitian yang sama dapat digunakan untuk organisasi atau institusi yang relatif sejenis. Artinya individu yang menjadi sasaran organisasi 'bisa diperlakukan' sebagai pelaku yang wajib berperilaku, sementara di lain pihak, organisasi berperilaku sebagai 'penguasa absolut'.

Model penelitian ini juga bisa digunakan untuk melengkapi model penelitian yang biasa digunakan untuk meneliti organisasi jasa, perdagangan atau manufaktur, yang individu sasarannya relatif bisa bebas memilih alternatif yang ditawarkan untuk memenuhi kebutuhannya. Faktanya, pada sektor-sektor ekonomi tersebut kegiatan organisasinya tidak hanya harus berusaha menjual produknya untuk mempertahankan kontinuitas usahanya, tetapi juga perlu berlaku adil pada setiap konsumennya.

\section{Daftar Pustaka}

Barsky, JD. and R. Labagh. 1992, Measurement, Market Research, Hotels and Motels, Factors, Customer Satisfaction, Consumer Attitudes, Cornell Hotel and Restaurant Administration Quarterly, 33 (5): 37-44.
Bloemer, J., KD. Ruter and P. Peeters, 1998, Investigating Drivers of the Bank Loyalty: the Complex Relationship between Image, Service Quality and Satisfaction, International Journal of Bank Marketing.

Chang, CH. and CY. Tu. 2005, Exploring Store Image, Customer Satisfaction and Customer Loyalty Relationship: Evidence from Taiwanese Hypermarket Industry, Journal of American Academy of Business.

Cords, D. 2006, Tax Protestors and Penalties: Ensuring Perceived Fairness and Mitigating Systemic Costs, Brigham Young University Law Review.

Disney, J, 1999, Customer Satisfaction and Loyalty: the Critical Elements of Service Quality, Total Quality Management.

Fitriandi, P., T. Birowo dan Y. Aryanto, 2007, Kompilasi Undang-Undang Perpajakan Terlengkap: Susunan Satu Naskah, Jakarta: Penerbit Salemba Empat.

Folger, R. and MA. Konovsky, 1989, Effects of Procedural and Distributive Justice on Reactions yo Pay Raise Decisions, Academy of Management Journal, 32 (1): 115-130.

Goldman, AH.2006, The Rationality of Complying with Rules: Paradox Resolved, Ethics, 116 (April): 453-470.

Grisaffe, D.2001, Loyalty-Attitude, Behavior and Good Science: A Third Take on the Neal-Brandt Debate, Journal 
UNISIA, Vol. XXXI No. 69 September 2008

of Consumer Satisfaction, Dissatisfaction and Complaining Behavior.

Huang, JH. and CY. Lin,2005, The Explanation Effects on Costumer Perceived Justice, Satisfaction and Loyalty Improvement: An Exploratory Study, The Journal of American Academy of Business.

Jawa Pos (2006), Pajak Hilang Rp 263 Triliun, Senin, 4 Desember: 1 dan 15.

(2007a), Usul Pemisahan DJP Mentok, Kamis, 25 Januari: 8 (2007b), 210 Aparat Pajak Kena Sanksi, Kamis, 1 Maret: 8

Jun, S., YJ. Hyun., JM. Gentry and CS. Song,2001, The Relative Influence of Affective Experience on Consumer Satisfaction Under Positive Versus, Journal of Consumer Satisfaction, Dissatisfaction and Complaining Behavior.

Lawton, JL., D. Weaver and B. Faulkner, 1998, Customer Satisfaction in Australian Timeshare Industry, Journal of Travel Research, 37(1): 30-38.

Leo, PY. and J. Philippe,2002, Retail Centers: Location and Customer's Satisfaction, The Service Industries Journal.

Mc Mahon, C. 2001, Collective Rationality and Collective Reasoning, Cambridge: Cambridge University Press.

Meuter, LM., AL. Ostrom, RI. Roundtree and MJ. Bitner, 2000, Self-Service Technologies: Understanding Customer
Satisfaction with Technology-Based Service, Journal of Marketing, 64 (3): 50-64.

Stephens, N. and KP. Gwinner, 1998, Why don't some People Complain? A Cognitive-emotive Process Model of Consumer Complaint Behavior, Academy of Marketing Science Journal, 26 (3): 172-189.

Tax, ST., SW. Brown and M. Chandrashekaran,1998, Custemer Evaluations of Service Complaint Experiences: Implications for Relationship Marketing, Journal of Marketing, 62 (1): 60-76.

Tian-Cole, S., JL Crompton and VL Willson 2002, An Empirical Investigation of the Relationships Between Service Quality, Satisfaction and Behavioral Intentions among Visitors to a Wildlife Refuge, Journal of Leisure Research, 34(1): 1-24.

Voss, GB., A. Parasuraman and D. Grewal, 1998, The Roles of Prince, Performance, and Expectations in Determining Satisfaction in Service Exchanges, Journal of Marketing, 62(2): 46-61.

Yu, CH., HC. Chang and GL. Huang ,2006, A Study of Service Quality, Costumer Satisfaction and Loyalty in Taiwanese Leisure Industry, The Journal of American Academy of Business, 9(1): 126-133.

Yuksel, A. and M. Rimmington, 1998, Customer-Satisfaction Measurement, 
Pengaruh Keadilan terhadap Kepuasan dan...; Albari

Cornell Hotel and Restaurant Administration Quartely, 39 (6): 60-68.

Zeithaml, VA., MJ. Bitner and DD. Gremler 2006, Service Marketing: Integrating
Customer Focus Across the Firm, $4^{\text {th }}$ ed., Singapore: McGraw-Hill Companies, Inc. 